\title{
Exocrine Pancreatic Cancer Pathologic Distant Metastasis TNM Finding v6
}

National Cancer Institute

\section{Source}

National Cancer Institute. Exocrine Pancreatic Cancer Pathologic Distant Metastasis

TNM Finding v6. NCI Thesaurus. Code C60940.

A pathologic finding about one or more characteristics of exocrine pancreatic cancer, following the rules of the TNM AJCC v6 classification system as they pertain to distant metastases. 